Gulsah Pamuk

Ege University, Emel Akin Vocation School

Ege Universitesi Emel Akin MYO, 35100, Bornova, Izmir, Turkey

\title{
Natural Fibres Reinforced Green Composites
}

Z naravnimi vlakni ojačeni zeleni kompoziti

\author{
Professional article/Strokovni članek \\ Received/Prispelo 07-2015 • Accepted/Sprejeto 03-2016
}

\begin{abstract}
Composites made from natural fibres and various bio polymers have recently attracted great attention. In this paper, the reasons for the popularity of green composites are highlighted. The disadvantages and modification methods of natural fibres are then summarized. Additionally, biodegradable polymers and a brief survey of the research work are pointed out.

Keywords: natural fibres, composite materials, biodegradable polymers, ecology
\end{abstract}

\section{Izvleček}

Kompoziti iz naravnih vlaken in različnih biopolimerov v zadnjem času zbujajo veliko pozornost. $V$ članku podani pregled osvetljuje vzroke za priljubljenost zelenih kompozitov. Povzeti so slabosti naravnih vlaken, metode njihove modifikacije in pregled biorazgradljivih polimerov ter kratek pregled izvedenih raziskav na tem področju.

Ključne besede: naravna vlakna, kompozitni materiali, biorazgradljivi polimeri, ekologija

\section{Introduction}

A green or an eco/ecological composite may contain natural fibres and natural polymers, or it can be a combination of natural fibres and a biodegradable polymer matrix [1]. Actually, natural raw materials have been used in composites since 1850. By combining shellac-resin and sawdust little boxes for photographs were produced until 1870. According to Müssig, in the 1920s and 1930s, the first natural fibre composites were manufactured in aircraft construction with the aim of creating lighter parts for primary structures. In the late 1930s, Henry Ford promoted their application in the automotive sector [2]. Automotive and aerospace industries still demonstrate an interest in using more natural fibre reinforced composites [3].

The reasons for this great interest are of course the environmental advantages and biological degradability of natural fibres. For example, if flax is burnt after having been used, no residues remain [4]. Natural materials like wood chips and flour are also

Corresponding author/Korespondenčna avtorica:

Gulsah Pamuk

Phone: +90 5327173426

E-mail: gulsah.pamuk@ege.edu.tr widely used because of their eco-friendly characteristics as fillers within thermoplastics in automotive and building applications [5]. Even though wooden materials are cheaper than natural fibres, it is expected that in the near future, due to extensive native forest destruction, their price will increase to a point at which they will be no longer able to compete with natural fibre composites. This is already the case for some native forest-depleted countries [6].

Other advantages of natural fibres in composite reinforcement are:

- natural fibres are abundant and renewable [7];

- production of natural fibres results in lower environmental impacts compared to glass fibre production [8];

- lower weight of natural fibre composites improves fuel efficiency and reduces emissions during the use phase of the component [9]. The weight reduction when conventional composite materials are replaced with natural fibre composites can reach even $26 \%$. More flax fibres have been progressively incorporated into natural fibre 
automotive components that require $83 \%$ less energy and are $40 \%$ less expensive than glass fibre components [10];

- end of life incineration of natural fibres results in energy and carbon credits;

- reduced tool wear [11];

- they are safer especially in automobile interiors as the fractures of natural fibre composites are not as sharp as the fractures of glass fibre composites [12].

Natural fibres used in composite reinforcement are split into four categories; seed, bast, leaf and fruit. Cotton is a seed fibre. The bast fibre group includes kenaf, hemp and flax, while sisal may be considered a leaf fibre. On the other hand, coir and banana are vegetable fibres [13]. According to Zampaloni 2007, bast fibres exhibit superior flexural strength and modulus of elasticity (MOE), whereas leaf fibres show superior impact properties [3]. Tensile strength and elastic modulus values of these fibres are given in Table 1.

Table 1: Tensile strength and modulus of elasticity of natural fibres used in composite reinforcement

\begin{tabular}{|l|c|c|}
\hline Fibre Type & $\begin{array}{c}\text { Tensile } \\
\text { Strength (MPa) }\end{array}$ & $\begin{array}{c}\text { Modulus of } \\
\text { Elasticity } \\
(\mathrm{GPa})\end{array}$ \\
\hline Flax [10] & 1100 & 100 \\
\hline Cotton [10] & $287-597$ & $5.5-12.6$ \\
\hline Jute [6] & $550-900$ & $17-26$ \\
\hline Sisal [6] & $400-700$ & $9-20$ \\
\hline Ramie [6] & 870 & 128 \\
\hline Coir [6] & $106-270$ & $3-6$ \\
\hline Banana [6] & $529-800$ & $7.7-32$ \\
\hline
\end{tabular}

Beyond the advantages mentioned below, natural fibres have some limitations and drawbacks, when they are used as reinforcements in composite materials, such as:

- the fibres are hydrophilic;

- the compatibility between hydrophilic fibres and hydrophobic matrices is low;

- the fibres are not resistant to high temperatures $\left(>200^{\circ} \mathrm{C}\right.$ );

- the fibres are short;

- the quality and consistency of properties is affected by factors which are hard to control such as climate impacts during growth and harvesting [14].

\section{Modification of natural fibres in composite materials}

The characteristics of composites depend on:

- the properties of fibre,

- the properties of matrix material,

- interfacial compatibility of fibre and matrix.

Natural fibres contain hydroxyl and other polar groups in their constituents [7]. This feature becomes a disadvantage when these fibres are used in composite materials since they meet with non-polar polymers. Polar groups are hydrophilic which causes the absorption of water in natural fibres. This nature leads to incompatibility and poor wettability in a hydrophobic polymer matrix and weak bonding in the fibre/matrix interface [11].

The surface adhesion between the fibre and the polymer plays an important role in the transmission of stress from the matrix to the fibre. If bonding between the fibre and the polymer matrix material is weak, then failure is inevitable in ultimate composite. The absorption of water in the pores and amorphous regions of natural fibres serves to reduce interfibrillar cohesion and to relieve internal fibre stresses [15]. Furthermore, the high moisture absorption property of natural fibres makes them less attractive for exterior applications [7], decreases their dimensional stability [6] and tends to rotting [16].

There are several methods existing which intend to improve surface adhesion between natural fibre and polymer matrix material. The basic objective, however, remains the same: to remove surface contamination and to provide an intimate contact between the surfaces. The simplest way is to roughen the surface so as to enhance the contact area and facilitate mechanical interlocking [11]. Modification methods are classified as physical and chemical.

\subsection{Physical methods of modification}

Physical treatments change structural and surface properties of natural fibres and thereby influence their mechanical bonding with the matrix [6]. Physical methods involve surface fibrillation, plasma, corona, dielectric barrier techniques etc.

Plasma can be defined as a partially ionized quasineutral gas. In this ionized gas there is the balance between the densities of negative and positive particles in macroscopic volumes and time. Plasma components include ions, electrons, UV and vacuum $\mathrm{UV}$ radiation. Plasma is thought to bring physical 
modification on the surface through roughening the fibre by the sputtering effect, producing thus an enlargement of the contact area that increases the friction between the fibre and the polymer.

Corona and dielectric barrier techniques are nonthermal plasma treatments. Corona discharges are relatively low power electrical discharges that take place at or near atmospheric pressure. The corona is generated by strong electric fields associated with small diameter wires, needles, or sharp edges on an electrode. Corona treatment is a difficult technique to be used on 3D objects. This limitation has highlighted the need for alternative, more 3D 'compliant' surface modification techniques such as the ozone and/or ultraviolet radiation (e.g. UV) light [11].

\subsection{Chemical methods of modification}

The compatibility and dispersability of fibre and matrix can be improved by developing a hydrophobic coating of a compatible polymer on the surface of a filler before being mixed with polymer matrix. Generally, coupling agents facilitate the optimum stress transfer at the interface between the fibre and the matrix. Coupling agents are molecules having two functions. The first is to react with $\mathrm{OH}$ groups of cellulose and the second is to react with functional groups of the matrix [7].

There are many types of coupling agents including surface-active agents and reactive chemistries, at times referred to as functional modifiers. Surfaceactive agents are materials that increase interfacial adhesion by acting as a solid surfactant and that do not form covalent bonds to the polymer matrix. Materials that form covalent bonds to either the fibre or the polymer matrix can be reacted in-situ during processing [17].

The selection of a coupling agent that can combine both strength and toughness to a considerable degree is important for a composite material. The most common coupling agents are silane, isocyanate and titanate based compounds, the chemical composition of which allows them to react with the fibre surface, which forms a bridge of chemical bonds between the fibre and the matrix [7].

Those options (physical and chemical modifications) are not attractive, even in terms of cost-benefit ratio, when the composites are designed for low strengthlow cost applications such as transit panels, because of the significant cost increase that might result from the use of chemicals or treatment apparatus [6].

\section{Matrix materials}

Matrix materials are divided into two categories as thermosets and thermoplastics. Thermosets cannot be melted once they have been cured since they are chemically crosslinked. But these matrices generally have quite good mechanical properties. Most common thermoplastics have low transition temperature, giving them quite low stiffness at room temperature and above. The low $\mathrm{Tg}$ also makes them very brittle at low temperatures, however, the lack of cross-linking is one of the big advantages of thermoplastics which makes them reshapeable and re-meltable [14]. Thermoplastics also offer many advantages. One of the advantages of thermoplastic matrix composites is their low processing costs. Other advantages are the design flexibility and the ease of moulding complex parts. Simple methods such as extrusion and injection moulding are used for the processing of these composites [18].

Most commonly used thermoset polymers in natural fibre reinforced composites are polyester, epoxies and vinylester. While natural fibres have been traditionally used to fill and reinforce thermosets, natural fibre reinforced thermoplastics, especially polypropylene composites, have attracted greater attention due to their added advantage of recyclability [8]. Other thermoplastics like polyethylene (PE) and polystyrene (PSI) have also been used in ecological composites.

No matter which polymer is used, high temperatures must be avoided due to the possibility of fibre degradation. When working with natural fibres, the processing temperature must be below $200^{\circ} \mathrm{C}$ [18] This also restricts natural fibre composites to relatively low temperature applications [19].

Low twisted yarns display a very low strength when tested dry in the air and, therefore, they cannot be used in processes such as pultrusion or textile manufacturing routes. On the other hand, by increasing the level of twist, a degradation of the mechanical properties is observed in impregnated yarns (e.g. unidirectional composites) similar to off-axis composites. Therefore, an optimum twist should be used to balance processability and mechanical properties [20]. On the other hand, strands of natural fibres are usually heavily twisted, and that can hinder infiltration or impregnation of the resin matrix into the fibre strands [21]. 


\subsection{Biodegradable polymers}

There are many different polymers of renewable materials. Biodegradable plastics can be based on natural or synthetic resins. Natural biodegradable plastics are based primarily on renewable resources (such as starch) and can be either naturally produced or synthesized from renewable resources [22].

PLA is a good example of thermoplastic biopolymer that is used today. Its basic monomer is lactic acid, which is derived from starch by fermentation. PLA is and was frequently used for biodegradable packing materials. However, numerous tests have shown that PLA is also suitable as a matrix for embedding fibres in composites [23]. Other studied biopolymers have been soy-oil based epoxy, starch, polycaprolactone (PCL), polyhydroxybutyrate (PHB), modified cellulose, acetic acid, polyester amide, natural rubber and gluten $[22,24]$.

Polyesters play a predominant role as biodegradable plastics due to their potentially hydrolysable ester bonds. Biodegradable polyesters which have been developed commercially and are in commercial development are PHA - polyhydroxyalkanoates, $\mathrm{PHH}$ polyhydroxyhexanoate, PHB - polyhydroxybutyrate, PHV - polyhydroxyvalerate, PLA - polylactic acid, PCL - polycaprolactone, PBS - polybutylene succinate, PBSA - polybutylene succinate adipate, AAC aliphatic-aromatic copolyesters, PET - polyethylene terephthalate, PBAT - polybutylene adipate/terephthalate and PTMAT - polymethylene adipate/terephthalate [22].
The problems with most of these polymers have been poor commercial availability, poor processability, low toughness, high price and low moisture stability [25].

\section{Preforms}

Natural fibres such as flax are usually avialable as short fibres. These short fibres are suitable for injection moulding process and for producing non woven mats. In both processes, short fibres are randomly orginised which causes relatively poor mechanical properties in resulting composites [20].

There are several studies available concerning the mechanical properties of green composites. A brief survey of the research work published in the field of natural fibre reinforced composites is given in Table 2 . According to the literature, preform types have been generally used in the form of nonwoven/fibre mat.

\section{Conclusion}

The aim of this article is to give a short overview of the reasons for the usage of green composites, disadvantages of natural fibres and their modification methods, matrix materials and research activities associated with these composite materials.

The research showed that there are many types of natural fibres and biopolymers available for green composites all of which have different characteristics and benefits. Although modifications and biopolymers increase the cost of ultimate composite, their environmental returns are undeniable.

Table 2: Literature survey of green composites

\begin{tabular}{|c|l|l|l|c|c|}
\hline \multirow{2}{*}{ Reference } & \multicolumn{1}{|c|}{ Fibre type } & \multicolumn{1}{|c|}{ Preform type } & $\begin{array}{c}\text { Matrix material } \\
\text { type }\end{array}$ & $\begin{array}{c}\text { Tensile } \\
\text { strength } \\
(\mathrm{MPa})\end{array}$ & $\begin{array}{c}\text { Impact } \\
\text { strength } \\
\left(\mathrm{kJ} / \mathrm{m}^{2}\right)\end{array}$ \\
\hline$[7]$ & $100 \%$ flax & nonwoven mat & epoxy & 57.79 & 13.69 \\
\hline$[26]$ & $100 \%$ flax & nonwoven mat & modified soy oil & 40 & \\
\hline \multirow{2}{*}[6]{} & $100 \%$ jute & fibre mat & PES & 43.0 & \\
\cline { 2 - 6 } & $100 \%$ sisal & fibre mat & PES & 34.6 & \\
\hline \multirow{2}{*}[27]{} & \multirow{2}{*}{$100 \%$ flax } & fibre mat & Palatal E240-02 & 47.9 & \\
\cline { 3 - 7 } & & fibre mat & Norpol 200-510 & 71.6 & \\
\cline { 3 - 7 } & & fibre mat & epoxy & 88.3 & \\
\cline { 3 - 7 } & & fibre mat & Norpol 420-100 & 79.2 & \\
\cline { 3 - 7 } & fibre mat & vinylester & 91.2 & \\
\hline
\end{tabular}




\begin{tabular}{|c|c|c|c|c|c|}
\hline [28] & $100 \%$ jute & nonwoven mat & PLA & 72.7 & 14.3 \\
\hline \multirow{5}{*}[29]{} & $100 \%$ kenaf & fibre mat & PP & 28 & 14 \\
\hline & $100 \%$ coir & fibre mat & $\mathrm{PP}$ & 10 & 24 \\
\hline & $100 \%$ sisal & fibre mat & $\mathrm{PP}$ & 35 & 28 \\
\hline & $100 \%$ hemp & fibre mat & $\mathrm{PP}$ & 52 & 26 \\
\hline & $100 \%$ jute & fibre mat & $\mathrm{PP}$ & 26 & 17 \\
\hline [30] & $100 \%$ flax & nonwoven mat & $\begin{array}{l}\text { cellulose acetate } \\
\text { propionate }\end{array}$ & & 10 \\
\hline \multirow{2}{*}[31]{} & \multirow{2}{*}{$100 \%$ jute } & plain weave & PES & 23.1 & \\
\hline & & flat knit & PES & 17.8 & \\
\hline [32] & flax $50 \%$, cotton $50 \%$ & denim fabric & HDPE & 35.8 & \\
\hline [20] & flax & plain weave & vinylester & 129 & \\
\hline \multirow{6}{*}[33]{} & \multirow{6}{*}{$100 \%$ flax } & \multirow{6}{*}{ fibre mat } & PPMA & 75 & \\
\hline & & & PLLA & 100 & \\
\hline & & & PLA & 100 & \\
\hline & & & PHB & 40 & \\
\hline & & & PBS & 50 & \\
\hline & & & PBAT & 30 & \\
\hline \multirow[t]{5}{*}[21]{} & jute $45 \%$, cotton $55 \%$ & plain weave & PES & 62.5 & \\
\hline & jute $39 \%$, cotton $61 \%$ & plain weave & PES & 72.1 & \\
\hline & jute $43 \%$, cotton $57 \%$ & plain weave & PES & 73.1 & \\
\hline & $100 \%$ jute & plain knit & PES & 19.8 & \\
\hline & $100 \%$ jute & plain weave & PES & 40 & \\
\hline$[34]$ & sisal and silk & $\begin{array}{l}\text { hand lay up } \\
\text { hand lay up }\end{array}$ & $\begin{array}{l}\text { PES } \\
\text { PES }\end{array}$ & $\begin{array}{l}18.95 \\
23.61\end{array}$ & \\
\hline$[3]$ & $\begin{array}{l}\text { kenaf } \\
\text { kenaf } \\
\text { kenaf } \\
\text { hemp } \\
\text { coir }\end{array}$ & $\begin{array}{l}\text { hand lay up } \\
\text { hand lay up } \\
\text { hand lay up } \\
\text { hand lay up } \\
\text { hand lay up }\end{array}$ & $\begin{array}{l}\mathrm{PP} \\
\mathrm{PP} \\
\mathrm{PP} \\
\mathrm{PP} \\
\mathrm{PP}\end{array}$ & $\begin{array}{l}45 \\
43 \\
51 \\
52 \\
10\end{array}$ & \\
\hline$[2]$ & $\begin{array}{l}\text { cotton } \\
\text { ramie }\end{array}$ & $\begin{array}{l}\text { multilayer web } \\
\text { multilayer web }\end{array}$ & $\begin{array}{l}\text { epoxy } \\
\text { epoxy }\end{array}$ & $\begin{array}{c}28 \\
100 \\
\end{array}$ & $\begin{array}{l}82 \\
38 \\
\end{array}$ \\
\hline$[35]$ & $\begin{array}{l}\text { sisal } \\
\text { sisal }\end{array}$ & $\begin{array}{l}\text { plain weave } \\
\text { twill weave }\end{array}$ & $\begin{array}{l}\text { PES } \\
\text { PES }\end{array}$ & $\begin{array}{l}28 \\
33 \\
\end{array}$ & \\
\hline$[36]$ & $\begin{array}{l}\text { abaca } \\
\text { man-made cellulose }\end{array}$ & & PLA & $\begin{array}{l}74 \\
92 \\
\end{array}$ & $\begin{array}{l}5.3 \\
7.9 \\
\end{array}$ \\
\hline$[1]$ & cotton & $\begin{array}{l}\text { spacer fabric } \\
\text { with weft inlay }\end{array}$ & PLA & 30.31 & 11.18 \\
\hline \multirow{4}{*}[37]{} & flax & $\begin{array}{l}\text { spacer fabric } \\
\text { with weft in-lay }\end{array}$ & epoxy & 41.45 & 53.80 \\
\hline & flax & $\begin{array}{l}\text { spacer fabric } \\
\text { with weft in-lay }\end{array}$ & vinylester & 54.70 & 49.23 \\
\hline & cotton & $\begin{array}{l}\text { spacer fabric } \\
\text { with weft in-lay }\end{array}$ & epoxy & 49 & 19.26 \\
\hline & cotton & $\begin{array}{l}\text { spacer fabric } \\
\text { with weft in-lay }\end{array}$ & vinylester & 42.41 & 17.27 \\
\hline
\end{tabular}




\section{References}

1. GACEVA, G.B., AVELLA, M., MALINCONICO, M., BUZAROVSKA, A., GROZDANOV, A., GENTILE, G., ERRICO, M.E. Natural fibre-eco composites. Polymer Composites, 2007, 28(1), 98-107, doi 10.1002/pc.20270.

2. MÜSSIG, Jörg. Cotton fibre-reinforced thermosets versus ramie composites: a comparative study using petrochemical and agro-based resins. Journal of Polymers and Environment, 2008, 16(2), 94-102, doi: 10.1007/s10924-008-0089-4.

3. ZAMPALONI, M., POURBOGHRAT, F., YANKOVICH, S.A., RODGERS, B.N., MOORE, J., DRZAL, L.T., MOHANTY, A.K., MISRA, M. Kenaf natural fiber reinforced polypropylene composites: a discussion on manufacturing problems and solutions. Composites Part A: Applied Science and Manufacturing, 2007, 38(6), 15691580, doi: 10.1016/j.compositesa.2007.01.001.

4. Van de VELDE, Kathleen, KIEKENS, Paul. Thermoplastic pultrusion of natural fibre reinforced composites. Composite Structures, 2001, 54(2-3), 355-360, doi: 10.1016/S0263-8223(01)00110-6.

5. UMER, R., BICKERTON, S., FERNYHOUGH, A. Characterising wood fibre mats as reinforcements for liquid composite moulding processes. Composites Part A: Applied Science and Manufacturing, 2007, 38(2), 434-448, doi: 10.1016/j. compositesa.2006.03.003.

6. d'ALMEIDA, J.R.M. Analysis of cost and flexural strength performance of natural fiber-polyester composites. Polymer-Plastics Technology and Engineering, 2001, 40(2), 205-215, doi: 10.1081/PPT-100000065.

7. JAYAMOL, George, SREEKALA, M.S., SABU, Thomas. A review of interface modification and characterization of natural fibre reinforced plastic composites. Polymer Engineering and Science, 2001, 41(9), 1471-1485, doi: 10.1002/pen.10846.

8. JOSHI, S.V., DRZAL, L.T., MOHANTY, A.K., ARORA, S., Are natural fiber composites environmentally superior to glass fiber reinforced composites? Composites Part A: Applied Science and Manufacturing, 2004, 35(3), 371-376, doi: 10.1016/j.compositesa.2003.09.016.

9. MOHANTY, A.K., DRAZL, L.T., MISRA, M. Engineered natural fiber reinforced polypropylene composites: influence of surface modifications and novel powder impregnation processing. Journal of
Adhesion Science and Technology, 2002, 16(8), 9991015, doi. 10.1163/156856102760146129

10. FOULK, Jonn, A., CHAO, Wayne, Y., AKIN, Danny, E., DODD, Roy, B., LAYTON, Patricia, A. Analysis of flax and cotton fiber fabric blends and recycled polyethylene composites. Journal of Polymers and the Environment, 2006, 14(1), 15-25, doi: 10.1007/s10924-005-8703-1.

11. MUKHOPADHYAY, S., FANGUEIRO, R. Physical modification of natural fibers and thermoplastic films for composites - a review. Journal of Thermoplastic Composite Materials, 2009, 22(2), 135-162, doi: 10.1177/0892705708091860.

12. MIAO, Menghe, FINN, Niall, Conversion of natural fibres into structural composites. Journal of Textile Engineering, 2008, 54(6), 165-177.

13. MILLER, Edward. Textiles: properties and behaviour in clothing use. $3^{\text {th }}$ edition. London : B.T. Batsford, 1992.

14. NYSTRÖM, Birgitha. Natural fibre composites : optimization of microstructure and processing parameters : Licentiate Thesis. Luleå : Luleå University of Technology, 2007, [online], [accessed: 3. 9. 2016]. Available on World Wide Web: $<$ http://epubl.ltu.se/1402-1757/2007/31/LTULIC-0731-SE.pdf $>$.

15. BALEY, Christophe. Analysis of the flax fibres tensile behavior and analysis of the tensile stiffness increase. Composites Part A: Applied Science and Manufacturing, 2002, 33(7), 939-948. doi: 10.1016/S1359-835X(02)00040-4.

16. STAMBOULIS, A., BAILLIE, C.A., GARKHAIL, S.K., van MELICK, H.G.H., PEIJS, T. Environmental durability of flax fibres and their composites based on polypropylene matrix. Applied Composite Materials, 2000, 7(5), 273-294, doi: 10.1023/A:1026581922221.

17. HOLBERY, James, HOUSTON, Dan. Naturalfiber-reinforced polymer composites in automotive applications. JOM, 2006, 58(11), 80-86, doi: 10.1007/s11837-006-0234-2.

18. SAHEB, D. Nabi, JOG, J. P. Natural fiber polymer composites: a review. Advances in Polymer Technology, 1999, 18(4), 351-363, doi: 10.1002/(SICI)10982329(199924)18:4<351::AID-ADV6>3.0.CO;2-X.

19. SGRICCIA, N., HAWLEY, M.C., MISRA, M. Characterization of natural fiber surfaces and natural fiber composites. Composites: Part A: Applied Science and Manufacturing, 2008, 39(10), 1632-1637, doi: 10.1016/j.compositesa.2008.07.007. 
20. GOUTIANOS, S., PEJIS, T., NYSTROM, B., SKRIFVARS, M. Development of flax fibre based textile reinforcements for composite applications. Applied Composite Materials, 13(4), 2006, 199-215, doi: 10.1007/s10443-006-9010-2.

21. CARVAlHO, L.H., de SOUZA, G.C., Almeida, J.R.M. Hybrid jute/cotton fabric-polyester composites: effect of fabric architecture, lamina stacking sequence and weight fraction of jute fibres on tensile strength. Plastics, Rubber and Composites, 2007, 36(4), 155-161, doi10.1179/ $174328907 X 191396$.

22. NAMPOOTHIRI, K. Madhavan, NAIR, Nimisha Rajendran, JOHN, Rojan Pappy. An overview of the recent developments in polylactide (PLA) research. Bioresource Technology, 2010, 101(22), 8493-8501, doi: 10.1016/j.biortech.2010.05.092.

23. GRAUPNER, Nina, HERRMANN, Axel S., MÜSSIG, Jörg. Natural and man-made cellulose fibre-reinforced poly(lactic acid) (PLA) composites: an overview about mechanical characteristics and application areas. Composites Part A: Applied Science and Manufacturing, 2009, 40(6-7), 810-821, doi: 10.1016/j.compositesa.2009.04.003.

24. ALIX, S., MARAIS, S., MORVAN, C., LEBRUN, L. Biocomposite materials from flax plants: preparation and properties. Composites Part A: Applied Science and Manufacturing, 2008, 39(12), 17931801, doi: 10.1016/j.compositesa.2008.08. 008.

25. OKSMAN, K., SKRIFVARS, M., SELIN, J.-F. Natural fibres as reinforcement in polylactic acid (PLA) composites. Composites Science and Technology, 2003, 63(9), 1317-1324, doi: 10.1016/ S0266-3538(03)00103-9.

26. WILLIAMS, George I, WOOL, Richard P. Composites from natural fibers and soy oil resins. Applied Composite Materials, 2000, 7(5/6), 421432, doi: 10.1023/A:1026583404899.

27. JOFFE, Roberts, WALLSTRÖM L., BERGLUND, L.A. Natural fiber composites based on flax matrix effects. International Scientific Colloquium, Modelling for Saving Resources. Riga, 2001, 54-59 [online], [accessed: 3. 9. 2016]. Available on World Wide Web: <http://www.modlab.lv/ publications/msr2001/pdf/54-59.pdf >.

28. PLACKETT, David, ANDERSEN, Tom Løgstrup, PEDERSEN, Walther Batsberg, NIELSEN, Lotte. Biodegradable composites based on 1-polylactide and jute fibres. Composites Science and Technology, 2003, 63(9), 1287-1296, doi: 10.1016/S0266-3538(03)00100-3.
29. WAMBUA, Paul, IVENS, Jan, VERPOEST, Ignaas. Natural fibres: can they replace glass in fibre reinforced plastics? Composites Science and Technology, 2003, 63(9), 1259-1264, doi: 10. 1016/S0266-3538(03)00096-4.

30. BJURENSTEDT, Anton, LARNEKLINT, Frida. $3 D$ biocomposites for automotive interior parts. MSc Thesis. Lulea : Lulea University of Technology, 2004 [online], [accessed: 3. 9. 2016]. Available on World Wide Web: <http://epubl.ltu.se/14021617/2004/245/LTU-EX-04245-SE.pdf>.

31. CARVALHO, L.H., CAVALCANTE, J.M.F., ALMEIDA, J.R.M. Comparison of the mechanical behavior of plain weave and plain weft knit jute fabric-polyester-reinforced composites. PolymerPlastics Technology and Engineering, 2006, 45(7), 791-797, doi: 10.1080/03602550600611933.

32. FOULK, Jonn A., CHAO, Wayne Y., AKIN, Danny E., DODD, Roy B., LAYTON, Patricia A. Enzyme-retted flax fiber and recycled polyethylene composites. Journal of Polymers and the Environment, 2004, 12(3), 165-171, doi: 10.1023/b:jooe.0000038548.73494.59.

33. BODROS, Edwin, PILLIN, Isabelle, MONTRELAY, Nicolas, BALEY, Christophe. Could biopolymers reinforced by randomly scattered flax fibre be used in structural applications? Composites Science and Technology, 2007, 67(3-4), 462470, doi: 10.1016/j.compscitech.2006.08.024.

34. KHANAM P. Noorunnisa, REDDY, M. Mohan, RAGHUK, K., JOHN, K., NAIDU, S. Venkata. Tensile, flexural and compressive properties of sisal/silk hybrid composites. Journal of Reinforced Plastics and Composites, 2007, 26(10), 1065-1070, doi: 10.1177/0731684407079347.

35. POTHAN, L.A., MAI, Y.W., THOMAS, S., LI, R.K.Y. Tensile and flexural behavior of sisal fabric/polyester textile composites prepared by resin transfer molding technique. Journal of Reinforced Plastics and Composites, 2008, 27(16-17), 1847-1866, doi: 10.1177/0731684408090342.

36. LEDZKI, Andrzej K., JASZKIEWICZ Adam, SHERZER Dietrich. Mechanical properties of PLA composites with man-made cellulose and abaca fibres. Composites Part A, 2009, 40(4), 404-412, doi: 10.1016/j.compositesa.2009.01.002.

37. PAMUK, Gulsah, CEKEN, Fatma. Comparison of the mechanical behavior spacer knit cotton and flax fabric reinforced composites. Industria Textila, 2013, 64(1), 3-7. 